\title{
Customer Satisfaction with Service Quality in Conventional Banking in Pakistan: The Case of Faisalabad
}

\author{
Salman Khalid (Corresponding author) \\ School of Management Studies, The University of Faisalabad, Faisalabad, Pakistan \\ Tel: 92-300-865-3949Ｅ-mail: Salmankhalid77@yahoo.com
}

Babak Mahmood

Assistant Professor, Department of Sociology, University of Sargodha, Sargodha, Pakistan

Muzaffar Abbas

School of Management Studies, The University of Faisalabad, Faisalabad, Pakistan

Shabbir Hussain

Punjab College of Commerce, Faisalabad, Pakistan

\author{
Received: August 12, $2011 \quad$ Accepted: September 26, $2011 \quad$ Published: November 1, 2011 \\ doi:10.5539/ijms.v3n4p165 \\ URL: http://dx.doi.org/10.5539/ijms.v3n4p165
}

\begin{abstract}
The purpose of this paper is to evaluate the customer satisfaction of banking industry in Pakistan general, and Faisalabad particular, based on various levels of customer perception regarding service quality. This is an empirical study based mainly on primary data collected through a well-structured questionnaire. The questionnaire has been personally administrated on the a sample size of 132, chosen respondents on a convenient basis from four Pakistani banks, i.e. Alfalah Bank Limited, Faysal Bank Limited, National Bank Limited, and The Bank of Punjab. This paper makes a useful contribution as there are only few studies dealing with the assessment of service quality in conventional banking sector of Pakistan. The result indicates that customer perceive highest satisfaction in the responsiveness area and lowest in the tangibles area. In order to achieve higher levels of service quality, the bank managers should redesign their strategies about customer satisfaction with respect to service quality.
\end{abstract}

Keywords: Customer satisfaction, Service quality, Conventional banking industry, Pakistan

\section{Introduction}

In services industries, the subject of service quality globally remains a critical one as service providers strive to maintain a comparative advantage in marketplace. Financial services in general, particularly banks; compete in marketplace with generally undifferentiated services and products, thereby service quality becomes a key competitive weapon (Stafford, 1996). A banking organization can only differentiate itself from competitors by providing high quality services. It is true that structural changes have resulted in banks to perform a greater range of activities, and enabling them to become more competitive with non-bank financial institutions (Angur et al., 1999). Presently, technological advancements are causing banks to revise their strategies for services offered to both individual and commercial customers. Furthermore, banks that excel in quality services can have distinct marketing edge since improved levels of service quality are related to higher revenue, higher customer retention, higher cross-sell ratios (Bennett \& Higgins, 1993), and increased market share (Bowen \& Hedges, 1993). In addition, the banks understand that customer will be loyal if they can produce greater value than their competitors (Dawes \& Swailes, 1999). Moreover, higher profits will be earned by banks if they can position themselves better than competitors within a specific market (Davies et al., 1995). Hence, banks should focus on service quality as a core competitive strategy (Chaoprasert \& Elsey, 2004). Therefore, customer satisfaction and 
service quality have become the focal point of all banking institution around the world (Hossain \& Leo, 2009), and Pakistan is not an exception.

Pakistani banking sector is continuously expanding and improving with diversified patterns of ownership due to an active participation of local and foreign stakeholders. The Pakistani banking sector comprises of a State Bank of Pakistan (SBP), which is central bank of country and a combination of local and foreign banks. A total of 53 banks currently are operating in Pakistan, five of which are publicly owned (First Women Bank Limited, National Bank of Pakistan, Sindh Bank Limited, The Bank of Khyber, and The Bank of Punjab), including four specialized banks (Industrial development Bank of Pakistan, SME Bank Limited, The Punjab Provincial Cooperative Bank Limited, and Zarai Taraqiati Bank Limited), seventeen private banks (Allied Bank Limited, Askari Bank Limited, Bank Alfalah Limited, Bank Al Habib Limited, Faysal Bank Limited, Habib Bank Limited, Habib Metropolitan Bank Limited, JS Bank Limited, KASB Bank Limited, MCB Bank Limited, NIB Bank Limited, SAMBA Bank Limited, SILKBANK Limited, Soneri Bank Limited, Standard Chartered Bank (Pakistan) Limited, Summit Bank Limited, and United Bank Limited), five Islamic Banks (AlBaraka Bank (Pakistan) Limited, BankIslami Pakistan Limited, Burj Bank Limited, Dubai Islamic Bank Pakistan Limited, and Meezan Bank Limited), also represented are the local branches of six foreign banks (including Barclays Bank PLC, Deutsche Bank AG- Pakistan Operations, Citibank N.A.- Pakistan Operations, HSBC Bank Middle East Limited - Pakistan Operations, Oman International Bank S.O.A.G - Pakistan Operations, and The Bank of Tokyo-Mitsubishi UFJ Limited - Pakistan Operations), eight micro finance banks (KASHF Microfinance Bank Limited, Khushhali Bank Limited, Network Microfinance Bank Limited, NRSP Microfinance Bank Limited, Pak Oman Microfinance Bank Limited, Rozgar Microfinance Bank Limited, Tameer Micro Finance Bank Limited, and The First Micro Finance Bank Limited), and eight development finance institutions (House Buliding Finance Company Limited, Pak Brunei Investment Company Limited, Pak-China Investment Company Limited, PAIR Investment Company Limited, Pakistan Kuwait Investment Company Limited, Pak Libya Holding Company Limited, Pak Oman Investment Company Limited, and Saudi Pak Industrial \& Agricultural Investment Company Limited) (www.sbp.org.pk). Moreover, as their current and saving accounts, all the commercial banks in Pakistan offer the same range of standard facilities you would expect to find anywhere in the world including, debit cards, credit cards, travelers cheques, money transfers, personal loans, vehicle loans, etc. selected banks also offer specialized services such as VIP accounts, ladies accounts, children and student's accounts, plus e-banking platforms such as telephone and PC banking which offer 24/7 access. Particularly, the expansion in private banking business, along with customized services, has created a cut-throat competition in this sector (Khalid \& Irshad, 2010).

\subsection{Research objectives}

The objective of the present study is to find out the relationships between service quality attributes (tangibles, reliability, responsiveness, empathy) and customer satisfaction in the conventional banking sector of Pakistan. The study seeks to identify the most important service quality attributes among tangibles, reliability, responsiveness, empathy, which experienced by the bank customers.

\section{Literature review}

\subsection{Service quality}

Research has indicated that service quality has been increasingly recognized as a critical factor in the success of any business (Parasuraman et al., 1988), and the banking industry in this case in not exceptional (Hossain \& Leo, 2009). Service quality has been widely used to evaluate the performance of banking services (Cowling \& Newman, 1995). The banks understand that customers will be loyal if they provide greater value (quality services) than their competitors (Dawes \& Swailes, 1999), and on other hand, banks can only earn high profits if they are able to position themselves better than competitor within specific market (Davies et al., 1995). Consequently, banks need to focus on service quality as a core competitive strategy (Chaoprasert \& Elsey, 2004).

Gronroos (2000) defined service as, "A service is a process consisting of a series of more or less intangible activities that normally, but not necessarily always, take place in interactions between the customer and service employees and/or physical resources or goods and/ or systems of service provider, which are provided as solutions to customer problems". Fogli (2006) defined term service quality as "a global judgment or attitude relating to particular service; the customer's overall impression of the relative inferiority or superiority of the organization and its services". 


\subsection{Customer satisfaction}

Customer satisfaction is one of the important outcomes of marketing activity (Spreng et al., 1996; Mick \& Fournier, 1999). Therefore, there are vast amount of studies on satisfaction in marketing literature (Oliver, 1997; Giese \& Cote, 2000). In today's highly competitive banking industry, customer satisfaction is considered as the essence of success (Siddiqi, 2010). Most of the studies have dealt with satisfaction of customers or consumers with products or services. Marketing researchers generally agree that satisfaction is a response to consumption related experiences (Yi, 1990; Anderson et al., 1994). According to File \& Prince (1992), customers who are satisfied tell others about their experiences and this increases Word of mouth (WOM) advertising.

Prabhakaran (2003) highlights that the customer is the king. According to Drucker (1954), the fundamental purpose of any business is to create customer satisfaction. Increasing customer satisfaction has been found to lead organization to higher future profitability (Anderson et al., 1994), increased buyer willingness to pay premiums, provide referrals, and use more products (Reichheld, 1996), and higher levels of customer retention and loyalty (Fornell, 1992). Giese \& Cote (2000), identified the components of satisfaction such as: Customer satisfaction is one kind of response (emotional or cognitive), the response emphases on a particular focus (product, consumption, experience, expectations etc), and response occurs at a particular time (after choice, based on accumulated experience, after consumption etc). Kotler (2000) defined satisfaction as a person's feelings of pleasure or disappointment resulting from comparing a product's or service's perceived performance (or outcome) in relation to his or her expectations. Hoyer \& MacInnis (2001) said that satisfaction can be associated with feelings of acceptance, happiness, relief, delight, and excitement.

\subsection{Customer satisfaction and service quality in banking industry}

Without any doubt, service quality is gaining more importance in banking industry (Munusamy et al, 2010). Both the marketing and service management literatures suggest that there is strong theoretical underpinning among customer satisfaction, customer loyalty and profitability (Hollowell, 1996). Levesque \& McDougall (1996) pointed out that customer satisfaction and retention are critical for retail banks, and investigate the major determinants of customer satisfaction (service quality, service features, situational factors and customer complaint handling), and future intentions in the retail bank sector. Bloemer et al. (1998) explore how image, perceived service quality and satisfaction determine loyalty in a retail bank. Armstrong \& Seng (2000) analyze the determinants of customer satisfaction in the banking industry (purchase intentions, transactional paradigm, and fairness (equity). The study of Lassar et al. (2000) examines the effects of service quality on customer satisfaction from two distinct methodological perspectives - technical/functional quality and SERVQUAL. Jamal \& Naser (2002) suggest that customer satisfaction is based not only on the judgment of customers towards the reliability of the delivered service, but also with customers' experiences with the service delivery process. Therefore, they report demographic differences (education, gender and income levels) in the degree of customer satisfaction. Hence, customer satisfaction with commercial and retail banking is composed of a wide variety of dimensions.

Thus, consumer satisfaction thus (delete it) reveals the general evaluation of the actions carried out by a given business in relation to expectations accumulated after various contact between the consumer and business (Bitner \& Hubber, 1994). If customers perceive that they are obtaining additional benefits from their relationship with establishment employees, their satisfaction level with the service provider will increase (Beatty et al., 1996). Relational benefits can then be considered as important factors for customer satisfaction with financial businesses. Therefore, relational benefits mean special treatment, social benefits and confidence, which were investigated by Gwinner et al. (1998), would have a strong influence on customer satisfaction with their habitual establishments.

\section{The research framework}

A research framework has been developed to find out the relationship between service quality attributes (tangibles, reliability, responsiveness, empathy), and customer satisfaction in the conventional banking sector of Pakistan. The figure 1 demonstrates the hypothesized relationships between the constructs i.e. tangibles, reliability, responsiveness, empathy, and customer satisfaction.

\subsection{Hypotheses development}

The hypothesises designed for this paper is based on the following assumptions:

- H1a: There is a positive association between tangibles and customer satisfaction in the conventional banking sector of Pakistan. 
- H2a: There is a positive association between reliability and customer satisfaction in the conventional banking sector of Pakistan.

- H3a: There is a positive association between responsiveness and customer satisfaction in the conventional banking sector of Pakistan.

- H4a: There is a positive association between empathy and customer satisfaction in the conventional banking sector of Pakistan.

\section{Methodology}

An empirical study has been designed to meet the objectives of the research. For this purpose, four banks have been chosen as universe randomly, whereas two banks belonged to the private sector (Bank Alfalah Limited and Faysal Bank Limited), other two belonging to the public sector. One of public sector bank (The Bank of Punjab) was established under the Government of Punjab province whereas other (National Bank of Pakistan) was governed by Federal Government of Pakistan.

The questionnaire has been designed on the basis of the study of researchers such as (Berry et al., 1985; Parasuraman et al., 1985; Zeithaml \& Bitner, 1996; Stafford, 1996). Berry et al., (1985) and Zeithaml \& Bitner (1996) who identified five dimensions of service quality: tangible (equipment, written material, personnel, and appearance of physical facilities), reliability (ability to deliver promised service and accurately), responsiveness (willingness to help customers and providing prompt services), assurance (Knowledge and ability of employees to inspire trust and confidence), and empathy (Caring and providing individual attention to each customer). Parasuraman et al., (1985) indicates that service quality consists of eleven dimensions: reliability, competence, responsiveness, access, courtesy, communication, credibility, security, competence, tangibles, and understanding of customer. Reliability is considered as essential dimension of service quality. Stafford (1996), focused on customer services on seven dimensions, such as relationships, bank atmosphere, rates and charges, ATM, available and convenient services, facilities of bank counter (tellers), and honesty/reliability of bank personnel. For present investigation we have constructed four dimensions:

1) Tangibles

2) Reliability

3) Responsiveness

4) Empathy

Permission to carry out the study was obtained from the Area Managers of concerned bank. The questionnaire was sent to different branches of each bank with a brief explanation of the questionnaire, with a copy of permission letter from area manager. The respondents were also given a written guarantee of confidentiality for information. Respondents (Customers) were asked to indicate the level of satisfaction or dissatisfaction which was derived from each of the four dimension of service quality. The scale ranged from 1 to 5 representing : $1=$ "Highly satisfied": 2 = "Satisfied": 3 = "Somewhat satisfied" : 4 = "Dissatisfied" : 5 = "Highly dissatisfied". The questionnaire consisted of 27 items. The questionnaire was split into two sections: demographics and customer satisfaction. The demographic questions in the survey included age, occupation (Student, Service provider, Job holder or Business man), education, gender, and monthly income. Answers to these questions provide a good picture of respondent's (customers) background. The Customer satisfaction questions covered service quality facets such as: bank location, bank environment, delivery of promised services, prompt service, security with respect to transactions, personal attention from employees, product range and attitude of employees. The data entry has been done for final analysis at the point of 132 completely filled questionnaires. The data from the returned questionnaire then entered into computer program statistical package for social sciences (SPSS) version 17 for analysis in batches after the survey responses received.

\section{Findings}

\subsection{Background of respondents}

The questionnaire (survey) was designed to seek information about the respondents, age, gender, education, and their occupation. Present analysis shows that $72.7 \%$ of the respondents are male and $27.3 \%$ are female. The detailed breakdown of the customer's background has been given in Table 1. It is seen from the Table 1 that $34.9 \%$ of respondents are in the age group of $41-50$ years. The next largest group of the respondents is in age group of $31-40$ years $(29.5 \%)$. About $22.7 \%$ respondents are from the age group of $20-31$ years. $8.3 \%$ of respondents are from age group of 51-60 years. Only 4.6\% respondents are in age group of 61 and above. In terms of qualification, there is a wide variation, Bachelors (45.6\%), Masters (38.9\%), MS/M.Phill (11.9\%), and 
$\mathrm{PhD}(4.2 \%)$. Among the 132 respondents, the highest numbers of the respondents are running their own business (48.6\%). However, Job holders, students, and other service providers represents $41.7 \%, 4.2 \%$, and 5.5\%, respectively.

\subsection{Descriptive statistics for each study constructs}

It is seen from the Table 2 Tangibility ranges from 1 to 4 with the Mean of 2.38, and the Standard Deviation of 0.825. Reliability ranges from 1 to 5 and the Mean and Standard Deviation is 2.49 and 1.095, respectively. For Responsiveness, Mean and standard Deviation is 2.48 and 0.895 respectively with the minimum and maximum value ranges from 1 to 4 . Empathy ranges from 1 to 5 and the Mean is 2.70, and Standard Deviation is .924. The minimum and maximum value for overall satisfaction is 1 to 4 , the Mean and Standard Deviation is 2.45 and 1.095 respectively. It has been observed in the Table 2 that almost all the Mean are similar. High standard deviation indicates that the data is wide spread, means that customer give a variety of opinion, whereas, low standard deviation means that they express close opinion.

\subsection{Hypotheses test}

A correlation coefficient is a statistical tool used to summaries the relationship between two variables with a single number that falls between -1.00 and +1.00 (Welkowitz et al., 2006). Morgan et al. (2004) stated that: -1.0 indicates perfect negative correlation, 0.0 indicate no correlation, and +1.00 shows perfect positive correlation. The Pearson correlation analysis obtained from the five intervals scaled variables in the Table 3 . The sample size $(\mathrm{N})$ is 132 and the significant level is $0.01(\mathrm{p} \leq 0.01)$.

\section{Hypothesis \# 1: Tangibles}

In the Table 3, it can be seen that the correlation ( $\mathrm{r}$ ) of tangibles is 0.461 and the significant level is 0.01 . It can be seen from Table 3 that the p-value is 0.000 , which is less than 0.01 . Therefore, we accept the null hypothesis, and concluded that there is moderate but positive $(\mathrm{r}=0.461)$ relationship between tangibles and customer satisfaction in the conventional banking sector of Pakistan. The study of Lai (2004) also found that tangibility is positively related to customer satisfaction.

\section{Hypothesis \# 2: Reliability}

The Table 3 shows that the correlation (r) is 0.505 for reliability and the p-value is 0.000 , which is less than the significant level 0.01 . Hence, the null hypothesis is accepted and concluded that there is large positive correlation between reliability and customer satisfaction in the conventional banking sector of Pakistan. Zim et al. (2010) stated that reliability is one of the significant factors of customer satisfaction.

\section{Hypothesis \# 3: Responsiveness}

According to the Table 3, the strongest predictor of customer satisfaction is responsiveness. The result indicates that the correlation (r) of responsiveness is 0.646 and p-value is 0.000 , which is less than 0.01 . Therefore, the null hypothesis is accepted and concluded that there is strong positive correlation between responsiveness and customer satisfaction in the conventional banking sector of Pakistan. Mengi (2009) also pointed out that responsiveness is positively related to customer satisfaction.

\section{Hypothesis \# 4: Empathy}

Referring to Table 3, it can be observed that correlation (r) for empathy is 0.491 and $p$-value is 0.000 . Hence, the null hypothesis is accepted and it can be concluded that empathy is positively (moderate) related to customer satisfaction in the conventional banking sector of Pakistan. Ladhari (2009) also found that empathy is positively related to customer satisfaction.

\subsection{Discussion of findings}

The hypotheses test confirms that all service quality attributes (Reliability, Responsiveness, Empathy, and Tangibles) are positively associated with customer satisfaction. Responsiveness shows the highest positive correlation $(\mathrm{r}=0.646)$ with satisfaction and reliability demonstrates the second highly positive correlation $(\mathrm{r}=$ $0.505)$ with customer satisfaction. Tangibles reveals the least but positive correlation $(\mathrm{r}=0.461)$ with customer satisfaction. A moderate but positive relationship $(r=0.492)$ between customer satisfaction and empathy was demonstrated in the hypotheses test. The discussion of the following service quality attributes are as follows:

Responsiveness: Responsiveness refers to the ability and willingness of the service provider (Banker) to meet customer needs. This study shows that responsiveness and customer satisfaction are highly positively correlated. The bank customer of (Public and Private) in Pakistan prefers a friendly bank, which is striving to help their 
banking operations. This willingness of banks to facilitate their customers is likely to have a significant and positive effect on customer satisfaction.

Reliability: Reliability refers to the extent to delivered services according to standards expected and promised by service provider, means the customer should get what they feel they have paid for. According to present study, there is a positive association between reliability and customer satisfaction. Data shows that customers are satisfied with customer support services, hospitality services and handling of customer's grievances. Consequently, customers are confident that their banks are fulfilling the promised terms and conditions which will not go against their expectations.

Empathy: The core concept of empathy is to understand customer needs and provide individual attention. This study indicates moderate but positive relationship between empathy and customer satisfaction. Means customers of banks are somehow satisfied with banking hours, personal attention given to them by bank staff, and information provided to them (Customer).

Tangibles: The hypotheses test of this study confirms that there is positive correlation between tangibles and customer satisfaction. Data shows that customers are satisfied with infrastructure facilities, modern equipment, staff's appearance, and décor of bank (Branch).

\section{Conclusion}

The above discussion indicates that customer satisfaction vary according to the nature of service. In this case, the highest customer satisfaction is demonstrated in the responsiveness area such as willingness to help customer, friendly attitude of staff, followed by the reliability area such as customer guidance, customer support. On the other hand, the moderate satisfactions are in the tangibles area, such as infrastructure facilities, décor, followed by empathy area such as banks business timing and return on investment. Due to the wide variation of the responses, both public and private banks need to consider the weak areas in order to meet customer requirements. Hence, to be successful in banking sector, banks must provide service to their customer that at least meets or better if exceeds their expectations, and the present study will provide some sort of guidelines to the policy makers (managers) of banks to take appropriate decision to improve the quality of services in Pakistani banking sector.

\section{Limitation of the study}

Four limitations have been identified in this study. First, the study only focused on public and private banks in Pakistan. The Foreign, Islamic, and other Micro financial institutions that have role in banking industry in Pakistan were excluded from this study. Second, the limited numbers of banks (only four) were covered under the study. Third, the sample size and number of actual respondents are limited. The researcher may use a bigger sample size to find out more about customer satisfaction and service quality. Finally, a more robust analysis is needed in financial service industry to reach at a strong conclusion.

\section{References}

Anderson, E.W., Fornell, C., \& Lehmann, D.R. (1994). Customer satisfaction, market share and profitability: Findings from Sweden. Journal of Marketing, 58, 53-66. http://dx.doi.org/10.2307/1252310

Angur, M.G., Nataraajan, R., \& Jaherea, J.S. Jr (1999). Service quality in the banking industry: an assessment of developing economy. International Journal of Marketing, 17(3), 116-125.

Armstrong, R.W., \& Seng, T.B. (2000). Corporate-customer satisfaction in the banking industry of Singapore. International Journal of Bank Marketing, 18 (3), 97-111. http://dx.doi.org/10.1108/02652320010339617

Beatty, S.E., Mayer, M., Coleman, J.E., Reynolds, K.E., and Lee, J. (1996). Customer-sales associate retail relationships. Journal of Retailing, 72(3), 223-47. http://dx.doi.org/10.1016/S0022-4359(96)90028-7

Bennett, D., \& Higgins, M. (1993). Quality means more than smiles. ABA Banking Journal, June, (46).

Berry, L.L., Parasuraman, A., \& Zeithaml, V.A. (1985). Quality counts in services, too. Business Horizons, May-June, 44-55. http://dx.doi.org/10.1016/0007-6813(85)90008-4

Bitner, M.J. (1995). Building service relationships: it's all about promises. Journal of the Academy of Marketing Science, 23 (4), 246-51. http://dx.doi.org/10.1177/009207039502300403

Bloemer, J., De Ruyter, K., \& Peeters, P. (1998). Investigating drivers of bank loyalty: the complex relationship between image, service quality and satisfaction. International Journal of Bank Marketing, 16(7), 276-86. http://dx.doi.org/10.1108/02652329810245984 
Bowen, J.W., \& Hedges, R.B. (1993). Increase service quality in retail banking. Journal of Retail Banking, 15, 21-28.

Chaoprasert, C., \& Elsey, B. (2004) Service quality improvement in Thai retail banking and its management implications. ABAC Journal, 24 (1), 47-66.

Cowling, A., \& Newman, K. (1995). Banking on people, Personnel Review, 24(7), 25-41. http://dx.doi.org/10.1108/00483489510095789

Davies, F., Moutinho, L., \& Curry, B. (1995). Construction and testing of a Knowledge-based system in retail bank marketing. International Journal of Bank Marketing, 13 (2), 235-260. http://dx.doi.org/10.1108/02652329510078613

Dawes, J., \& Swailes, S. (1999). Retention sans frontiers: issues for financial services retailers. International Journal of Bank Marketing, 17(1), 36-43. http://dx.doi.org/10.1108/02652329910254037

Drucker, Peter F. (1954). The Practice of Management. New York: Harper \& Row.

File, K.M., \& Prince, R.A. (1992). Positive word of mouth: Customer satisfaction and buyer behavior. International Journal of Banking Marketing, 10(1), 25-29. http://dx.doi.org/10.1108/02652329210007867

Fogli, L. (2006). Customer Service Delivery. San Francisco: Jossey-Bass.

Fornell, Claes. (1992). A National Customer Satisfaction Barometer: The Swedish Experience. Journal of Marketing, 56 (1), 6-21. http://dx.doi.org/10.2307/1252129

Giese, L., \& Cote, J. (2000). Defining Consumer satisfaction. Academy of Marketing Science Review, 1.

Gronroos, C. (2000). Service Management and Marketing: A Customer Relationship Management Approach. (2nd ed.). West Sussex: John Wiley \& Sons, Ltd.

Gwinner, K.P., Gremler, D.D., \& Bitner, M.J. (1998). Relational benefits in services industries: the customer's perspective. Journal of the Academy of Marketing Science, 26 (2), 101-14. http://dx.doi.org/10.1177/0092070398262002

Hossain, M., \& Leo, S. (2009). Customer perception on service quality in retail banking in Middle East: the case of Qatar. International Journal of Islamic and Middle Eastern Finance and Management, 2(4), 338-350. http://dx.doi.org/10.1108/17538390911006386

Hoyer, W. D., \& MacInnis, D. J. (2001) Consumer Behaviour. (2nd ed.). Boston, Houghton Mifflin Company

Jamal, A., \& Naser, K. (2002). Customer satisfaction and retail banking: an assessment of some of the key antecedents of customer satisfaction in retail banking. International Journal of Bank Marketing, 20(4), 146-60. http://dx.doi.org/10.1108/02652320210432936

Khalid, S., \& Irshad, M.Z. (2010). Job satisfaction among bank employees in Punjab, Pakistan: A comparative study. European Journal of Social Sciences, 17(4), 570-577.

Kotler, P. (2000). Marketing Management. (10th ed.). New Jersey, Prentice-Hall.

Ladhari, R. (2009). Assessment of the psychometric properties of SERVQUAL in the Canadian banking industry. Journal of Financial Services Marketing, 14(1), 70-82. http://dx.doi.org/10.1057/fsm.2009.2

Lai, T.L. (2004). Service Quality and perceived value's impact on satisfaction, Intention and usage of short message service (SMS). Information Systems Frontiers: Special Issue: Industrial Information Systems Frontiers, 6(4), 353-368.

Lassar, W.M., Manolis, C., \& Winsor, R.D. (2000). Service quality perspectives and satisfaction in private banking. Journal of Services Marketing, 14 (3), 244-71. http://dx.doi.org/10.1108/08876040010327248

Levesque, T., \& McDougall, G.H.G. (1996). Determinants of customer satisfaction in retail banking, International Journal of Bank Marketing, 14 (7), 12-20. http://dx.doi.org/10.1108/02652329610151340

Mengi, P. (2009). Customer Satisfaction with Service Quality: an empirical study of Public and Private sector banks. IUP Journal of Management Research, 8(9), 7-17.

Mick, D., \& Fournier, S. (1999). Rediscovering satisfaction. Journal of Marketing, 63(4), 5. http://dx.doi.org/10.2307/1251971

Morgan, G., Leech, N., Gloeckner, G., \& Barrett, K. (2004). SPSS for Introductory Statistics. (2nd ed.). New Jersey: Lawrence Erlbaum Associates, Inc. 
Oliver, R.L. (1997). Satisfaction: A behavioral perspective on consumer. New York, McGraw-Hill.

Parasuraman, A., Zeithaml, V.A., \& Berry, L.L. (1985). A conceptual model of service quality and implications for future research. Journal of Marketing, 49 (4), 41-50. http://dx.doi.org/10.2307/1251430

Parasuraman, A., Zeithaml, V.A., \& Berry, L.L. (1988). SERVQUAL- a multiple-item scale for measuring consumer perceptions of service quality. Journal of Retailing, 64(1), 12-40.

Prabhakaran, S., \& Satya, S. (2003). An insight into Service Attributes in Banking Sector. Journal of Services Research, 3(1), 157-169.

Reichheld, Frederick. (1996). The Loyalty Effect. Cambridge, MA: Harvard Business School Press.

Siddiqi, K.O. (2010). Interrelations between service quality attributes, customer satisfaction and customer loyalty in the retail banking sector in Bangladesh. International Trade \& Academic Research Conference (ITARC), (pp. 1-26). London.

Spreng, R.A., Mackenzie, S.B., \& Olshavsky, R.W. (1996). A re-examination of the determinants of consumer satisfaction. Journal of Marketing, 19(4), 491.

Stafford, M.R. (1996). Demographic discriminators of service quality in the banking industry. The Journal of Services Marketing, 10(4), 6-22. http://dx.doi.org/10.1108/08876049610124554

Welkowitz, J., Cohen, B.H., \& Ewen, R.B. (2006). Introductory statistics for the Behavioral Sciences. (6th ed.). New Jersey: John Wiley \& Sons, Inc.

Yi, Y. (1990). A critical review of consumer satisfaction. In V.A. Zeithaml (Ed.), Review of marketing, (pp. 68-123). Chicago: American Marketing Association.

Zeithaml, V.A., \& Bitner, M.J. (1996). Services Marketing. New York, McGraw-Hill.

Table 1. Background of respondents

\begin{tabular}{|l|l|}
\hline & Percentage \\
\hline Age (Years) & \\
\hline $20-30$ & 22.7 \\
\hline $31-40$ & 29.5 \\
\hline $41-50$ & 34.9 \\
\hline $51-60$ & 8.3 \\
\hline 61 and above & 4.6 \\
\hline & 100.0 \\
\hline Gender & \\
\hline Male & 72.7 \\
\hline Female & 27.3 \\
\hline & 100.0 \\
\hline Education & \\
\hline Bachelors & 45.6 \\
\hline Masters & 38.3 \\
\hline MS/M.phill & 11.9 \\
\hline PhD & 4.2 \\
\hline & 100.0 \\
\hline Occupation & \\
\hline Business man & 48.6 \\
\hline Job holder & 41.7 \\
\hline Student & 4.2 \\
\hline Other (service providers) & 4.5 \\
\hline & 100.0 \\
\hline &
\end{tabular}


Table 2. Descriptive statistics

\begin{tabular}{|c|c|c|c|c|c|}
\hline & $\mathbf{N}$ & Minimum & Maximum & Mean & $\begin{array}{c}\text { Std. } \\
\text { Deviation }\end{array}$ \\
\hline Overall satisfaction & 132 & 1 & 4 & 2.45 & 1.029 \\
\hline Tangibles & 132 & 1 & 4 & 2.38 & .825 \\
\hline Reliability & 132 & 1 & 5 & 2.49 & 1.095 \\
\hline Competence & 132 & 1 & 4 & 2.48 & .895 \\
\hline Empathy & 132 & 1 & 5 & 2.70 & .924 \\
\hline Valid N (list-wise) & 132 & & & & \\
\hline
\end{tabular}

Table 3. Correlation

\begin{tabular}{|c|c|c|c|c|c|c|}
\hline & & $\begin{array}{c}\text { Customer } \\
\text { satisfaction }\end{array}$ & Tangibles & Reliability & Responsiveness & Empathy \\
\hline \multirow[t]{3}{*}{$\begin{array}{l}\begin{array}{l}\text { Customer } \\
\text { satisfaction }\end{array} \\
\end{array}$} & Pearson Correlation & 1 & $.461(* *)$ & $.505(* *)$ & $.646(* *)$ & $.491(* *)$ \\
\hline & Sig. (2-tailed) & & .000 & .000 & .000 & .000 \\
\hline & $\mathrm{N}$ & 132 & 132 & 132 & 132 & 132 \\
\hline \multirow[t]{3}{*}{ Tangibles } & Pearson Correlation & $.461(* *)$ & 1 & $.604(* *)$ & $.525(* *)$ & $.522(* *)$ \\
\hline & Sig. (2-tailed) & .000 & & .000 & .000 & .000 \\
\hline & $\mathrm{N}$ & 132 & 132 & 132 & 132 & 132 \\
\hline \multirow[t]{3}{*}{ Reliability } & Pearson Correlation & $.505(* *)$ & $.604(* *)$ & 1 & $.619(* *)$ & $.579(* *)$ \\
\hline & Sig. (2-tailed) & .000 & .000 & & .000 & .000 \\
\hline & $\mathrm{N}$ & 132 & 132 & 132 & 132 & 132 \\
\hline \multirow[t]{3}{*}{ Responsiveness } & Pearson Correlation & $.646(* *)$ & $.525(* *)$ & $.619(* *)$ & 1 & $.668(* *)$ \\
\hline & Sig. (2-tailed) & .000 & .000 & .000 & & .000 \\
\hline & $\mathrm{N}$ & 132 & 132 & 132 & 132 & 132 \\
\hline \multirow[t]{3}{*}{ Empathy } & Pearson Correlation & $.491(* *)$ & $.522(* *)$ & $.579(* *)$ & $.668(* *)$ & 1 \\
\hline & Sig. (2-tailed) & .000 & .000 & .000 & .000 & \\
\hline & $\mathrm{N}$ & 132 & 132 & 132 & 132 & 132 \\
\hline
\end{tabular}

** Correlation is significant at the 0.01 level (2-tailed).

Table 4. Summary of the null hypotheses test

\begin{tabular}{|c|c|c|}
\hline Null Hypotheses & Descriptions & Results \\
\hline H1a & $\begin{array}{l}\text { There is positive association between } \\
\text { tangibles and customer satisfaction in } \\
\text { the conventional banking sector of } \\
\text { Pakistan. }\end{array}$ & Accepted \\
\hline $\mathrm{H} 2 \mathrm{a}$ & $\begin{array}{l}\text { There is positive association between } \\
\text { reliability and customer satisfaction in } \\
\text { the conventional banking sector of } \\
\text { Pakistan. }\end{array}$ & Accepted \\
\hline H3a & $\begin{array}{l}\text { There is positive association between } \\
\text { responsiveness and customer } \\
\text { satisfaction in the conventional banking } \\
\text { sector of Pakistan. }\end{array}$ & Accepted \\
\hline $\mathrm{H} 4 \mathrm{a}$ & $\begin{array}{l}\text { There is positive association between } \\
\text { empathy and customer satisfaction in } \\
\text { the conventional banking sector of } \\
\text { Pakistan. }\end{array}$ & Accepted \\
\hline
\end{tabular}




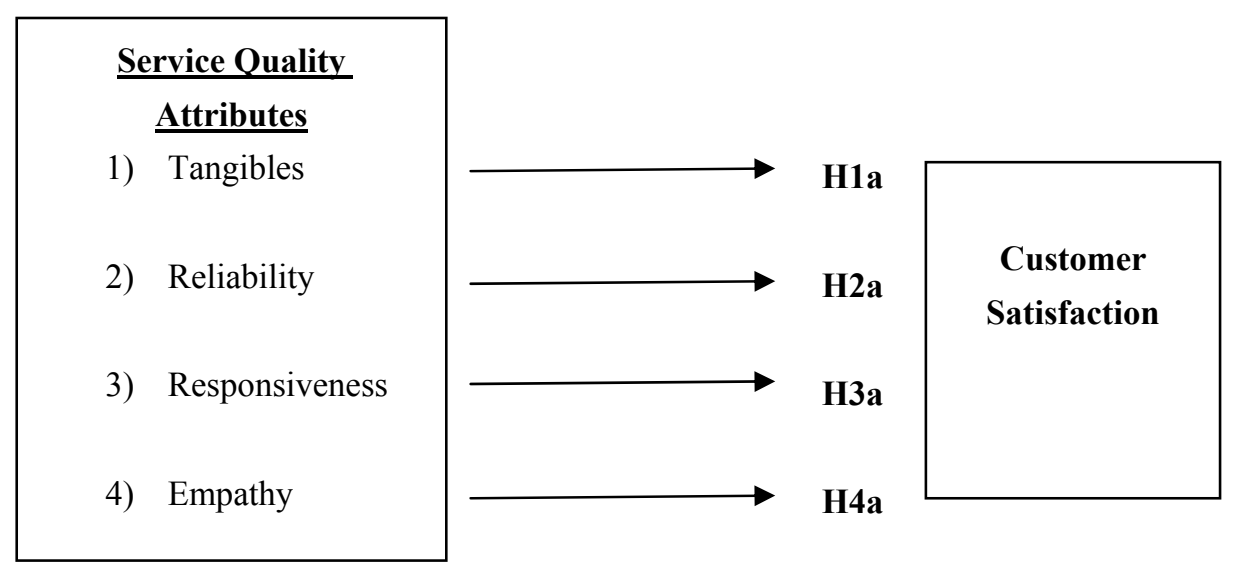

Figure 1. Research Framework 